\title{
Female leadership: perceptions, reflections, and challenges in public administration
}

\author{
RenAta Kessler Miltersteiner ${ }^{1}$ \\ FÁTIMA BAYMA DE OLIVEIRA ${ }^{2}$ \\ LYGIA GonÇALVES COSTA HRYNIEWICZ ${ }^{3}$ \\ ANDERSON DE SOUZA SANT'ANNA ${ }^{4}$ \\ LUIZ CARLOS MOURA ${ }^{2}$
}

\author{
1 Secretaria de Estado de Fazenda do Estado do RIO de JaneIro, RIO de JaneIro - RJ, BrazIL \\ 2 Fundação Getulio Vargas (FGV EBAPE) / Escola Brasileira de AdMinistração Pública e de EMpresas, Rio de JANEIRO - RJ, BRAZIL \\ ${ }^{3}$ Universidade Federal do RIO de JANEIRO (UFRJ) / NUCLEO de PESQUISA EM ESTRATIFICACAO E TRAJETORIAS SOCIAIS, RIO DE JANEIRO - RJ, BRAZIL \\ 4 Fundação Getulio Vargas (FGV EAESP) / Escola de Administração de EMPresas de SÃo Paulo, SÃo Paulo - SP, Brazil
}

\begin{abstract}
Discrimination against women in strategic positions is a recurring issue in the labor market, particularly in Brazil. Even though women generally have higher qualifications than men, this is not reflected in their salaries or positions. The causes of such limitations have historical, social, and psychological roots. This article aims to understand better the challenges faced by women in the public administration of the Brazilian executive branch. The study is based on the barriers to reaching leadership positions, such as "Glass Ceiling," "Leadership Labyrinths," and "Queen Bee," commonly described in the international and national literature on the theme. The study is organized in two stages. In the first, a qualitative approach was adopted, involving semi-structured and in-depth interviews with leaders - Under Secretaries - working in the government of the State of Rio de Janeiro. The second stage adopted a quantitative approach, with a questionnaire applied to female managers working at the State Secretariat of Finance and Planning of Rio de Janeiro. As a result, it appears that women still suffer from prejudices and barriers associated with male codes of professional advancement. However, most women indicate no direct prejudice, claiming that they have grown and reached strategic positions on their own merits.
\end{abstract}

Keywords: Female leadership. Women's career. Public administration. Equal opportunity.

\section{Liderança feminina: percepções, reflexões e desafios na administração pública}

\section{Resumo}

A discriminação sofrida pelas mulheres em posições estratégicas é fato recorrente no mercado de trabalho, em particular no Brasil. Mesmo que, geralmente, elas possuam maior qualificação que os homens, isto não se reflete nos seus salários e nos cargos por elas ocupados. As causas de tais limitações possuem raízes históricas, sociais e psicológicas. Neste artigo objetiva-se melhor compreender desafios enfrentados na ocupação de posições de liderança por mulheres na administração pública do executivo brasileiro, tendo por base barreiras comumente descritas na literatura internacional e nacional sobre o tema do alcance de postos de liderança - "teto de vidro", "labirintos de liderança", "abelha rainha". Metodologicamente, o estudo compreende duas etapas. A primeira, de abordagem qualitativa, compreende entrevistas semiestruturadas e em profundidade com lideranças - Subsecretárias - da Administração Pública do Rio de Janeiro. Na segunda fase, quantitativa, fez-se uso de survey, aplicado a gestoras da Secretaria de Estado de Fazenda e Planejamento Fluminense. Nos resultados, constata-se que a mulher ainda sofre preconceitos e enfrenta barreiras associadas aos códigos masculinos de ascensão profissional. Ainda assim, a maioria das entrevistadas indica não sofrer preconceito direto, afirmando o crescimento e o alcance de posições estratégicas por méritos próprios.

Palavras-chave: Liderança feminina. Carreira feminina. Administração pública. Igualdade de oportunidade.

\section{Liderazgo femenino: percepciones, reflexiones y desafíos en la administración pública}

\section{Resumen}

La discriminación de mujeres en cargos estratégicos es un hecho recurrente en el mercado laboral, en particular, en Brasil. Aunque, generalmente, las mujeres cuentan con una mayor cualificación que los hombres, eso no se refleja en los sueldos y en los puestos por ellas ocupados. Las causas de dichas limitaciones tienen raíces históricas, sociales y psicológicas. El objetivo de este artículo es comprender mejor los desafíos enfrentados por las mujeres para ocupar posiciones de liderazgo en la Administración Pública del Poder Ejecutivo brasileño, tomando como base barreras comúnmente descritas en la literatura internacional y nacional disponible sobre el tema puestos de liderazgo - "Techo de cristal”, "Laberintos del liderazgo", "Abeja reina"-. Metodológicamente, el estudio consta de dos etapas. La primera, de abordaje cualitativo, incluye entrevistas semiestructuradas y en profundidad a liderazgos -Subsecretarias- de la Administración Pública de Río de Janeiro. En la segunda fase, cuantitativa, se hicieron surveys a gestoras de la Secretaría de Estado de Hacienda y Planificación Fluminense. Como resultado, se constata que la mujer todavía es víctima de prejuicios y barreras asociados a códigos masculinos de ascenso profesional. Sin embargo, la mayoría indica no sufrir prejuicios directos y afirma haber crecido y alcanzado cargos estratégicos por sus propios méritos.

Palabras clave: Liderazgo femenino. Carrera femenina. Administración Pública. Igualdad de oportunidades. 


\section{INTRODUCTION}

The Industrial Revolution ( $18^{\text {th }}$ and $19^{\text {th }}$ centuries) was an important milestone in the process of female insertion in the labor market. Working conditions were precarious, especially for women and children. However, the twentieth century witnessed the prominence of women's demands for positions in the political, organizational, and educational sphere (MELO and THOMÉ, 2018).

After the Second World War, the conquests of women in the labor market became evident, exposing the issue of the sexual division of labor as a relevant subject for study by the market and in the academia. Understanding and responses to the women's condition of inferiority were sought, especially in liberal and Marxist currents. For liberal feminism, the subordination of women stems from the historical-cultural process, in which women find themselves indoctrinated to take care of their offspring and to be submissive, and it is up to men to be the lords of reason and responsible for supporting the family. For this structure to change, more significant insertion of women in the world of work is suggested, so that society sees this group as active and relevant. This approach supports the idea of men and women as equal within the law and enjoying the same rights. From this perspective, the meaning of feminism is linked to the conquest of "equal rights" - such as the struggle unleashed by American "suffragists" - but this is more focused on the individual than on the collective (MELO and THOMÉ, 2018). The liberal movement also questions society's labeling of the male-female sexual division, proposing that meritocracy is the path of dissolution of differences. Regardless of whether they are male or female, liberals argue that the consideration of the individual's degree of ability is a priority.

According to a Marxist perspective, feminist theories argue that capitalism operates to perpetuate male domination, especially regarding the control of the means of production and violence. For Haraway (2004), men would be intrinsically linked to the production process, rising without barriers in public life, leaving women the role of taking care of family and home. Women are, therefore, assigned a restricted role in society, reinforcing the space for men in the labor market and the public sphere. The task of ending these unequal relationships entails a radical transformation, especially in socio-economic relationships (MELO and THOMÉ, 2018).

For Oliveira (1993), despite the rights won regarding the labor relationships, the growing defense around female employability, as well as the improvement of their qualification levels, women began the twentieth century in inferior conditions, compared to working men. Hirata and Kergoat (2017) state that the idea of a sexual division of labor began to gain ground after feminist struggles for recognition of housework.

In this context, the studies have been directed at women's equal participation in the formal labor market. However, when comparing the participation of both genders in the paid labor market, there is a definite male predominance, especially in leadership positions (MELO and THOMÉ, 2018, p. 112). For Scott (1986), occupational mobility leads women to adopt practices that imitate male's attitudes. In this process of seeking to reach a position of equality by imitation, gender differences became more evident.

In the labor market and domestic activities, there are still demonstrations of the power and domination that men exert throughout history, even if these demonstrations, nowadays, are subtler. Despite the possibilities for women guaranteed by law, numerous situations of discrimination continue, indicating that there is still a long way to go concerning equal rights (BETIOL, 2000; HURLEY, 1999; MARVIN and BRYANS, 1999; CARVALHO, 2001).

Also, it is important to recognize the lack of self-confidence observed among women, paired with the culture of male superiority that influences the image that women have about themselves and the way the market perceives them (HRYNIEWICZ and VIANNA, 2018). Men have more space in social life, are considered the head of the household, and responsible for the finances. These assumptions are still valid, although going through changes at a slow pace.

The participation of women in society is enshrined in Brazil only after the Constitution enacted in 1934, providing for women's right to vote (OLIVEIRA, MENEZES and SANT'ANNA, 2012). This late conquest indicates the lack of opportunities for female participation in the market and the countries' political context. However, even though becoming financially independent, women still face barriers to achieve social and psychological independence, since society still perceives them as an "accessory" (KANAN, 2010). 
The relevance of this study lies in the evidence that men occupy most of the management positions in Brazil, although there are more women than men pursuing higher education, especially in the area of education (MELO and THOMÉ, 2018). Data from the National Household Sample Survey - PNAD (IBGE, 2017) indicates that women stay in school for longer than men (9.3 and 8.9 years, respectively). The adjusted rate of net school attendance of higher education is $26.8 \%$ for women, and $19.7 \%$ for men, a stable percent difference in comparison to the numbers of 2016.

The fact that women have more years of education than men could indicate that they have greater technical knowledge for positions of direction and management, a type of knowledge considered crucial in high-level positions. nder, organizations, a The Public Administration, in this sense, should better reproduce this difference, given that positions are filled through an entrance exam.

This context helps to understand that feminism has never focused on the superiority of women. On the contrary, it has emphasized equality and social justice in the labor market. In this context, one of the most sensitive themes of women's insertion in the labor market is that of female leadership. Gradually women reach management and power positions, become leaders, and their attitudes motivate increasing numbers of researchers to study the phenomenon.

\section{THEORETICAL FRAMEWORK}

\section{Gender, organizations and labor}

According to Irigaray (2011), it is natural for companies to defend a more functional and neutral administrative environment to achieve their financial goals, thus silencing the emergence of minorities. On the other hand, the workforce in organizations has been gender diversified, which challenges the idea of neutrality, technicality, and homogeneity of organizations. In this sense, the discussion of gender differences in organizations is current and necessary, and as the more organizations learn about such differences, the more they can expand their performance and increase market opportunities.

It is important to start the discussion by recognizing that gender does not reflect anatomy, but relates to the way the individual identifies or expresses himself socially. Biology can identify an individual's gender according to their reproductive cells. However, when establishing categories and typifications between men and women, the theme is no longer purely biological but also culturally based (JESUS, 2012).

In this context, women struggle to overcome the condition of 'minority.' For decades they have struggled to be recognized in the most diverse instances of society, especially in organizations. The institution, although "modernized," ignores the need for management policies and practices based on diversity in its broad sense (SIQUEIRA, SALES and FISCHER, 2016).

In Brazil, the regulation and conduct of diversity policies at the organizational level have a pragmatic nature. Companies seem to be limited to measures that fulfill legal requirements. The debate on diversity is sensitive, and management practices do not necessarily guarantee the adherence of organizations to the issue as a cause, and it does not guarantee the active inclusion of minorities.

According to Pérez-Nebra and Torres (2014, p. 528, our translation), it cannot be ignored that inclusion goes beyond diversity. For the authors, "[...] its operation depends on managing diversity in order to create an organizational environment that enables everyone to develop their potential while achieving the company's goals." In other words, inclusion is an achievement in terms of treatment, coexistence, and trust established with other workers in organizations.

As a result, it is essential to outline a path of inclusion that is aligned with business models, allowing assimilation more organically and strategically. In short, diversity must be understood and not instrumentalized, favoring the resignification of organizational culture and work and leadership styles (SIQUEIRA, SALES and FISCHER, 2016). The discourse organizations practice regarding diversity and inclusion cannot focus solely on immediate results but on their ethical and morally just content, indispensable to the social function of businesses. 


\section{Women and leadership}

As Teixeira (2015, p. 14, our translation) observes, leadership can be understood as "[...] the process of influencing others to do what the leader wants, or the ability to influence a group to act towards the group's objectives." It is noteworthy, therefore, that not every manager is a leader, since that, beyond the attributions of a position, leadership is something intrinsic.

Leadership studies have addressed gender issues. Nogueira (2012), for instance, argues that the focus of culture on people, and the women's ease of communication, are portrayed as leadership skills commonly associated with women.

Women are on the path of occupying strategic positions because they have more years of education and often better technical training. This advantage, however, does not translate in a higher number of women in high-level positions due to barriers such as the male leadership style.

However, society has started to debate the importance of human subjectivity - desire, innovation, creativity, "sparkle in the eye" - in the production process. This movement has opened space to discuss a "female leadership style." In practice, however, it is not simple for female managers to follow a female leadership style. It is common to face prejudice, gender stereotypes, and need to conform to ways of acting and being evaluated in organizations.

In this sense, women experience double-bind paradoxes: the female behavior is stereotyped as 'ineffective;' more "assertive" behaviors are understood as masculinized, and may damage the women's social image (NOGUEIRA, 2012). Therefore, they are subject to a dilemma about leadership style, an ambiguity that the academic discourse treats with metaphors, such as the "Leadership Labyrinth" and "Queen Bee Syndrome."

\section{Barriers to female leadership}

The classic "glass ceiling" metaphor, although widely used in academia, has been joined by a number of others, including the "labyrinth," which investigates the various barriers that women face when seeking to occupy positions at more strategic levels (OLIVEIRA, MENEZES and SANT'ANNA, 2012; HRYNIEWICZ and VIANNA, 2018). Eagly and Carly (2007) mention five main barriers: prejudice, resistance to female leadership, leadership style, demands of family life, social capital.

Authors such as Arvatea, Galileab and Todescatc (2018), and Derks, Van Laarb and Ellemers (2016) use the "Queen Bee" metaphor to illustrate challenges faced by women in contemporary processes of professional advancement. According to the authors, the bee society registers three varieties of individuals: the queen, the drone, and the workers. All its members have self-defined roles according to their nature and life cycle. The queen's job is to lay the eggs that will produce the next queen, the next drones, and the workers. The queen bee has important characteristics and is the base of the hive, as she is the only fertile female. If more than one queen bee is born, the first to be born is the queen. Drones only have to fertilize the queen. That done, they die. The workers are the sterile females of the hive. The queen bee is thus dominated by her very nature.

As in the hive, corporate life presents female individuals integrated into male-dominated structures. In this context, the term "queen bee syndrome" is imputed to women who seek professional fulfillment in male-dominated spaces and in doing so, instead of getting support from other women, distance themselves from them. Through this attitude, they adjust to the male culture, strengthening the detriment of a female way of being (ARVATEA, GALILEAB and TODESCATC, 2018; DERKS, VAN LAARB and ELLEMERS, 2016).

For Derks, Van Laarb and Ellemers (2016), there are two reasons for such behavior: competition and survival. After all, since childhood, the woman learns that she must be the best to achieve the perfect marriage, entering a natural dispute with other women. Growing up, this culture that is present in her subconscious exposes her to more competitive organizational behavior.

The authors argue that the queen bee phenomenon does not constitute gender bias, but a form of survival, a response to the discrimination and threat experienced in the workplace. They state that women "[...] may assimilate to masculine definitions of leadership as they move up the organizational ladder" (DERKS, VAN LAARB and ELLEMERS, 2016, p. 37). 
Intriguingly, the authors show that the behavior of queen bees legitimizes gender inequality. Women themselves are critical of other women instead of acting with communality and empathy (characteristics typically attributed to them). They endorse the notion that women are less ambitious and committed than men, remaining at a disadvantage.

Queen bees believe they have gained leadership space by trusting themselves and their potential. They understand professional success as a result of personal efforts and merits. Therefore, any other woman must go through the same afflictions and struggles if they want to be successful. Because she possesses the masculine characteristics necessary for leadership, she does not feel she should collaborate with the others.

This behavior is not an atypical consequence of female personality but arises in response to the woman's insertion in environments in which the female gender is devalued. This argument is based on the theory of social identity, which advocates that individuals base their identity, in part, on gender. It turns out that members of undervalued groups, realizing that the typical characteristics of their home group are considered undervalued and unimportant, feel their identity threatened (TAJFEL and TURNER, 1979; VAN LAARB and ELLEMERS, 2016).

Thus, the higher the position in organizational structures, the fewer women occupying that position. At the same time, those who achieve leadership positions find out that men in the same situation make more money than women. This context leads to two classic ways to break the gender paradigm: to act to increase the number of representatives of the group (collective) or to work individually to achieve positions, behaving as established by the current paradigm (individual).

In this spectrum, co-operating, as one woman among others, indicates that all are as good as men, allowing greater emphasis on the inherently feminine characteristics of leadership. However, it is possible to observe the existence of fear of attracting attention to characteristics attributed to women (attention shared between work and family, for example), and the strategy of individual merit is often used in response to such fears. Putting herself as an isolated successful case is a behavior that moves women away from the issue of gender, joining the dominant paradigm.

\section{Women in Public Administration}

Research from the Brazilian Institute of Geography and Statistics (IBGE, 2017) reveals that, for the period 2012-2016, women's compensation represented $75 \%$ of men's compensation, a difference justified by the fact that women dedicate less time to work in the market. However, even if the time spent at work increases, the difference in compensation remains. Controlling the difference by hours worked, the ratio observed in 2016 was 86.7\% (IBGE, 2017). In the public sector - as a rule - salaries are equal, but men usually occupy the positions.

In addition, there are fewer women in the labor market, and the gender breakdown corroborates studies that indicate gender segmentation: paid domestic service continues as an eminently female occupation (92.3\%) and construction as a stronghold male (96\%) (MELO and THOMÉ, 2018). Men generally go to higher-paid engineering and computer positions in the labor market, while women go to the humanities (SCOTT, 1986). Notwithstanding migration to male-dominated positions, wage differentiation persists (IBGE, 2017).

The IBGE (2017) states that, on average, women receive a $24.4 \%$ lower income than men. Also, $6 \%$ of men are employers, compared to only $3.3 \%$ of women; while $3.6 \%$ of women are contributing family workers, this percentage drops by half $(-1.5 \%)$ for males.

In 2016, when adding the hours devoted to household activities and the hours in the labor market, women worked more than men, with an average workload exceeding 54 hours per week (men averaged 51.5 hours per week) (IBGE, 2017).

Wage gaps are commonly related to factors that strongly connect women to family. These factors are "interruptions" in a woman's career such as pregnancy and the upbringing of children; society's perception of women's values; and the supposed preference of women for a balance between personal life and work, which differs from the male view of searching for better job positions. These elements corroborate the culture that defines men as providers and women as caregivers to offspring. 
This occupational and wage inequality is observed in both the private and public sphere. It should be noted that, at the time of this research, none of the approximately twenty Secretariats in the Executive Public Administration of the State of Rio de Janeiro, was headed by women, not even the Secretariat of State and Human Rights and Policies for Women and the Elderly (SEFAZ, 2018).

Against this backdrop, the next step is to connect and discuss the theoretical elements raised here with the practice observed in public administration. The central question that guided the research is: What is the role of metaphors in the contemporary dynamics of work and female leadership?

\section{METHODOLOGY}

This study used a qualitative and quantitative approach, involving semi-structured and in-depth interviews, as well as the application of a questionnaire consisting of questions measured using five-point Likert scales.

To this end, $100 \%$ of the Under Secretaries of the Rio de Janeiro executive public administration were contacted using the "Snowball" technique, which helped to approach subjects - in this case, public servants working in the second-level of the state apparatus - working in the institutions targeted by the study (VOGT, 1999). The research managed to interview ten Under-Secretaries of State, according to the profile outlined in Table 1.

Table 1

Interviewee profile

\begin{tabular}{c|c|c|c|c}
\hline Code & Qualification & Sector they work in & Age (years) & Marital state \\
\hline 101 & PhD in Economics & Finance & 44 & Single \\
\hline 102 & $\begin{array}{c}\text { Master in accounting and } \\
\text { financial accounting }\end{array}$ & Budgeting & 45 & Married with children \\
\hline 103 & Contabilidade & Budgeting & 44 & Divorced no children \\
\hline 104 & Education & Pension & 63 & Married with children \\
\hline 105 & Administration & Transport & 32 & Divorced with children \\
\hline 106 & Engineering & Civil House & 47 & Married with children \\
\hline 108 & Education & Human resources & 42 & Divorced no children \\
\hline 109 & PhD in political science & Technology & 42 & Divorced no children \\
\hline 10 & Master in accounting & Accounting & 32 & Married with children \\
\hline
\end{tabular}

Source: Elaborated by the authors.

The interviews were conducted face-to-face with an average duration of 45 minutes, totaling 7 hours of interviews and about 240 transcription pages. The transcribed data were then submitted to treatment through content analysis by category (BARDIN, 2011), obtaining five central themes associated with barriers experienced in the occupational trajectories of the interviewees: prejudice; resistance to female leadership; leadership styles; demands of family life, and investment in social capital. 
The information obtained through the interviews was used to build a questionnaire, which allowed to measure, in a quantitative manner, factors associated with barriers to the rise of female professionals to leadership positions, in second-level (managers) of the Rio de Janeiro Planning Secretariat. The questionnaire was sent to all female managers of the state Planning Secretariat, and 90 of them responded. After undergoing exploratory analysis, involving the verification of outliers and extreme univariate and multivariate data, the final sample included 50 complete and valid questionnaires (Table 2).

Table 2

Profile of questionnaire respondants

\begin{tabular}{c|c|c|c}
\hline \multirow{2}{*}{ Demographic data } & Categories & Frequence & $\%$ \\
\hline \multirow{3}{*}{ Marital status } & Single & 8 & $16 \%$ \\
\cline { 2 - 4 } & Married/ living together & 31 & $62 \%$ \\
\cline { 2 - 4 } & Divorced/Separated/widowed & 11 & $22 \%$ \\
\hline \multirow{2}{*}{ Children } & Yes & 27 & $54 \%$ \\
\cline { 2 - 4 } & No & 23 & $46 \%$ \\
\hline \multirow{3}{*}{ Education } & High school & 1 & $2 \%$ \\
\cline { 2 - 4 } & Degree & 10 & $20 \%$ \\
\cline { 2 - 4 } & Master/PhD & 28 & $22 \%$ \\
\hline
\end{tabular}

Source: Elaborated by the authors.

Based on the items of the questionnaire - built from the categories identified in the interviews (qualitative part) - and on the theoretical framework, the following hypotheses were proposed:

Hypothesis 1: The greater the femininity (or masculinity) of the female manager, the greater the communality (agency) and the gender identity (male/female);

Hypothesis 2: The more agentic/masculine is the female manager, the lower the vestige of prejudice (the greater the discrimination denial);

Hypothesis 3: The more agentic/masculine, the lower the resignation (the lower the resistance);

Hypothesis 4: The more agentic/masculine, the greater the resilience in the management career;

Hypothesis 5: The more agentic/masculine, the greater the acceptance in the management career;

Hypothesis 6: The more agentic/masculine, the greater the distance; and less willingness to support other women;

Hypothesis 7: The more agentic/masculine, the greater the career commitment.

\section{FINDINGS AND DISCUSSION}

\section{Barriers to rising and exercising leadership according to female public leaders interviewed}

Regarding gender-related prejudices experienced in work environments, most of the interviewees (06) indicate, at first, that they were not the object of prejudice. Paradoxically, when asked about the existence of prejudices suffered by other women, all of them answered it does exist. The interviewees revealed events - although they had been ignored - where there was prejudice.

It can be inferred that the interviewees, when avoiding to admit the existence of prejudice, seek to protect their success from any questioning. In other words, they seem to emphasize that their success is eminently linked to "objective factors," their gender-independent skills, and ability to achieve positions on equal and meritorious terms with men. That is, prejudice 
seems to be more associated with conscious or unconscious constructions of "fragility" of women's position in organizational dynamics than with structural or cultural aspects:

No, no discrimination. I think you have to be sure of the job position you want. It is no use accepting such a position and not thinking that your life will change... because it will (IO3).

No, I don't see prejudice [...] before taking office, I was probed to know about my future if I intended to have children, these things (I10).

Other answers, however, point to the existence of prejudice, particularly observing the lack of women in senior management positions. Even though the women passed the entrance exam to work in public administration positions and are usually welleducated, there are few of them in strategically and politically relevant positions. One interviewee points out, "[...] there is a lack of respect regarding the way women exercise leadership; they are labeled as 'hysterical' or 'neurotic'." Other barriers pointed out relate to occupational polarization strategies, leaving women with less valued areas and positions (SUSSKIND and SUSSKIND, 2017):

Why can women only belong to the Under Secretary for Women? Or they have to work on Education, or something related to women; if she is black, why does one assume she has to work in an Under Secretary that promotes racial equality? (I01).

Eagly and Carli (2007) point to the existence of a differential set of beliefs about the female and male characteristics of exercising leadership. Women are traditionally considered communal, and men are agentic. Being agentic is translated as being a good leader, highlighting elements such as proactivity, dynamism, pragmatism, and emphasis on results. Being agentic is considered a male characteristic; the possibility of non-communal or androgenic women is ignored. Agentic and androgenic women adopt masculine behaviors regarding leadership and management. These leaders, are in what Eagly and Carli (2007), call a "double bind," scaping the rule and often stigmatized:

\section{[...] my team took a long time to get used to me, with my way of working. They complained that I arrived too confident, when in fact I just wanted to get the work done (I1); and I think the biggest challenge was that I left sector $x$ and went to the commercial area, which was not only and exclusively a professional challenge; it was a challenge in terms of attitude. I left an attitude of respecting, responding, to a more attitude aggressive, seeking to gain market for the business (14).}

Regarding characteristics relevant to professional growth and the challenges and barriers to women's empowerment to gain positions of greater responsibility and leadership, once again, the agentic culture is characterized as "the right leadership," which leads "many women to behave by this standard." The interviewees pointed out that such behaviors are disseminated subtly or by internal instruments of professional development and performance evaluation. As a result,

[...] I do not doubt that being pragmatic is a good trait for those seeking leadership in more strategic positions. All of us who have come this far have this characteristic" (I5).

Consistent with the theory that tends to denote stronger male leadership styles, most respondents are inclined to reproduce them. Probably to assert their power and authority, they seem to adopt assertiveness, particularly in the face of demands for results. Typical characteristics associated with the exercise and legitimation of leadership were very similar: assertiveness, pragmatism, impersonality. Only two interviewees indicated aggregating profiles:

I am a steam roller. My way of being is because I believe in people, I believe they can do what has to be done; so I do not accept if they don't (109).

When I became chief of staff, there were only men. And my position as chief of staff was disturbing for both men and women. You are recognized on Women's Day, and that is it (I06).

The interviews also bring to light "woman-work-family" relationships. Due to cultural factors, the family side is commonly mentioned as significant in such triangulation. Findings by Eagly and Carli (2007) show that women tend to work fewer hours to care for their families and are more likely to leave their careers if they have to decide between them. Contrary to what was observed by these authors, the interviewees' reports do not indicate problems in this regard. It is possible that the type of 
institution - organization in the public sector - has specific characteristics that minimize its impacts compared to professionals from private sector institutions:

No, it didn't cause a problem in my career to have children, but it was tiring. But I could handle it. Until my first husband said: the training course or me? I chose the course and then things got clearer and we separated (106).

For the interviewees, society's understanding that women are the ones who should take care of the family is outdated. Contrary to this cultural trait, they have professional ambitions, but these ambitions must be aligned with the desire to start a family. For them, to find a partner who respects such a decision is more challenging than dealing with organizational factors:

It is fundamental (having family). And I think a woman can have everything. She can start a family and succeed professionally. It is a matter of dividing tasks. It is not only the woman who is responsible for the family, it is not only the woman who has to be available; this notion leads to a deteriorating relationship (I01).

The interviewees also stressed that they did not change their workload. According to them, however, family support proved to be fundamental, both in understanding absences and in supporting domestic and maternal activities:

I have a regular life out of the labor market. I wake up early, make breakfast, take care of my son and husband. If I'm at a party and the phone rings, I go out and answer it. They understand my position; I have no problem with that. My family supports me, and although it is tiring, it is what I like to do (IO7).

Moreover, they point out that taking care of the family and, concomitantly, occupying a leadership position eventually allows them to prove and legitimize their capacity, which is tested by the challenges inherent to the dual roles, in the family and the market.

I have a small one-year-old son. I got pregnant while in office, took maternity leave, and came back. Nothing has changed. On the contrary, I work harder to prove that I can keep both. My husband helps, and it has worked. We are a family, and it has worked (I09).

The single or divorced interviewees state that this is a matter of choice between their profession or partner, leading them to believe that reaching the highest level presupposes a decision that means "giving up building a family or investing in affective relationships:"

In my divorce, the issue that led to separation was the fact that my husband did not want to grow, to improve. He is an intelligent, handsome man, but he valued other things than work. And I wanted to grow professionally; Thus, we started to enter in a confrontation because of these different views (104).

For many, having a "safe place" makes a difference, whether family - children or husband -, or parents, or even a professional therapist. It was unanimous the importance they attribute to personal life, as a condition for better professional performance, even if it means

to go alone without a companion. You need to have emotional support; a therapist will not give you this support. You really need it when you give up certain areas of your life [...]. That is, you do need to have support, whether from your mother, your husband, but you need to have a safe place (I01).

During the interviews, female managers presented their definitions of what it means to be a mother or have a family. One of the interviewees, however, raises a relevant issue that deserves further considerations:

I am not an ordinary mother. [...] My daughter, for example, I fight like a mother in another way, I am the President of the Council her school is part of, and she is very proud. I am not an ordinary mother, but who is an ordinary mother these days? You can't be limited by the stereotype. I am constantly questioning. [...] I may not remember to cut her hair every month, but my way of being a mother is this, to look for the future that way. And she loves it (105).

Family is an issue pointed as "problematic," hindering professional growth (glass ceiling). For them, however, the most significant pressures are not in the organizational environment but come from family members. According to the manager, 
Female leadership: perceptions, reflections, and challenges in public administration
Renata Kessler Miltersteiner | Fátima Bayma de Oliveira Lygia Gonçalves Costa Hryniewicz | Anderson de Souza Sant'Anna

families often do not understand why they choose a career or choose not to have children. These choices often put them in a position of "incomplete women:"

Because of my choice to not be a mother, I am more discriminated by my friends and out there, than at work. Friends who wouldn't do what I did, who prefer not to work, reduce living expenses, and get pregnant and have children. They think I should drop everything, take maternity leave and take care of the child because time goes by and the child will suffer, they make you feel guilty even before you have a child. You can't have children because you won't give attention, but what does it mean reaing kids properly? I know people who are stay-at-home moms who don't pay the least attention to their children and working moms who give their children a lot more attention (I10).

In addition to the category family-work relationship, investments in social capital, in particular, networking and establishing social and professional bonds, are pointed out in the literature as an essential element for professional growth in any area. A recent study by Lee, Marshall, Rallis et al. (2018) suggests that social capital is even more necessary for the advancement of managers than the performance of traditional managerial skills. However, many women resent not being able to mobilize this side as well as men, limiting their aspirations for professional advancement:

I think we should be more available for that. For you to compete, you need to be available all the time. Get home late, and no one has starved, no one is waiting for you. Things are happening. I think we need to work harder because of this: more organized, more disciplined, trying to know the subject in depth to be able to be quicker; while the guy is thinking, we do it faster and have the same result (IO3).

Characteristics of female leadership also emerge as a relevant analytical category. The ten managers interviewed show very similar tones of voice and attitude, demonstrating assertiveness and objectivity. When asked about traits or characteristics that women commonly manifest when in leadership positions, the vast majority mention having technical knowledge as something crucial. According to the reports, the concern to be better than the opposite sex, although veiled, is present. More delicate behaviors of compassion or emotion, they say, often put them at risk of being labeled "weak leadership."

In this context, the "Queen Bee Syndrome" manifests in the interviews, regarding leadership characteristics concerning other women, especially with subordinates:

Women do not believe in themselves, and there is discrimination among them. Men are raised to receive care, and women are raised to take care of others (104).

Still regarding collaboration with other women, three interviewees report that their mentors, or people who somehow collaborate with their professional development process, are men:

When I started to work as a civil servant, there was a guy who did this work. It was something boring, and as I was young, he taught me this budget part. It's difficult because there are a lot of specific things in public administration (I03).

For the interviewees, there is a difficulty in approaching women hierarchically superior to others. They believe, however, that their subordinates can grow professionally by "deciding between work and family." In other words, "willing to pay the price":

I think women can often stand out, but I think that throughout life there is this issue of women deciding between working life and motherhood. Only after this decision can the woman fight for her space as a leader (106).

In short, identifying and categorizing the main barriers was possible through the female managers interviewed focused on five major themes: prejudice, resistance to female leadership, leadership styles, demands of family life, and investment in social capital. As explained in the methodology, these categories and their respective indicators served as the basis for the 
construction of a questionnaire, later applied to female managers in an organization in public administration. The questionnaire results are presented in the following topic.

\section{Barriers to women leadership according to the interviewed female public managers}

Table 3 reports descriptive statistics of socio-demographic and professional factors of the questionnaire respondents, as well as the statistics of categories established and studied when interviewing managers occupying second-level positions on the public institution analyzed in this research.

Table 3

Quantitative data: managers of the second-level of state secretaries

\begin{tabular}{|c|c|c|c|c|}
\hline & Average & Standard Deviation & Minimum & Maximum \\
\hline Age & 39.41 & 8.44 & 10 & 55 \\
\hline Experience & 16.87 & 7.41 & 1 & 30 \\
\hline Time in public administration & 10.29 & 7.09 & 0 & 30 \\
\hline Time in management & 4.79 & 4.07 & 1 & 20 \\
\hline Number of subordinates & 7.81 & 9.98 & 0 & 43 \\
\hline Number of female Subordinates & 4.02 & 4.32 & 0 & 16 \\
\hline Femininity & 4.11 & 0.63 & 2.6 & 5 \\
\hline Masculinity & 3.86 & 0.59 & 2.5 & 5 \\
\hline Communality & 6.12 & 0.62 & 4.3 & 7 \\
\hline Gender identity & 4.03 & 0.46 & 3 & 5 \\
\hline Agency & 5.87 & 0.74 & 4.5 & 7 \\
\hline Discrimination denial & 4.38 & 1.16 & 2.3 & 7 \\
\hline Resignation & 4.46 & 1.58 & 1.3 & 7 \\
\hline Resilience & 6.12 & 0.85 & 3.3 & 7 \\
\hline Acceptance & 5.13 & 1.16 & 2 & 6.6 \\
\hline Distancing & 2.63 & 1.1 & 1 & 5 \\
\hline Willingness & 3.79 & 1.06 & 1.3 & 7 \\
\hline Commitment & 3.56 & 1.12 & 1 & 6 \\
\hline
\end{tabular}

Source: Elaborated by the authors.

Note: All latent variables (extracted from a set of questions asked in the questionnaire) were obtained based on the average of answers related to each one of the items. For example, the item "Femininity" was composed of ten questions based on specific literature, and the values displayed in the table consider the average of these ten values, reported on a Likert scale. A similar rationale is valued to the variables "Masculinity," "Communality," "Gender identity," "Agency," "Discrimination denial," "Resignation," “Resilience," "Acceptance," "Distancing," “Disposition," and "Commitment."

Table 4 shows the results of the correlation matrix considering the categories examined. As a result, there is a strong positive association between age and years of experience $(\rho=0.777)$, professional experience, and time working in public administration $(\rho=0.589)$, as well as between time in management and time working in public administration $(\rho=0.666)$. Among the latent variables, it is worth highlighting the positive and significant correlation between masculinity and agency leaders $(\rho=0.641)$, masculinity and willingness $(\rho=0.651)$, masculinity and commitment $(\rho=0.722)$, willingness and agency $(\rho=0.675)$, and between commitment and willingness $(\rho=0.711)$.

Although the correlations are in line with the theoretical and they corroborate hypotheses, it is worthwhile proceeding with more detailed analysis presented below. 
Table 4

Correlation matrix

\begin{tabular}{|c|c|c|c|c|c|c|c|c|c|c|c|c|c|c|c|c|c|}
\hline & & (1) & (2) & (3) & (4) & (5) & (6) & (7) & (8) & (9) & (10) & (11) & (12) & (13) & (14) & (15) & (16) \\
\hline (1) & Age & 1.0000 & & & & & & & & & & & & & & & \\
\hline (2) & Experience & $0.7776 *$ & 1.0000 & & & & & & & & & & & & & & \\
\hline (3) & $\begin{array}{l}\text { Time in public } \\
\text { administration }\end{array}$ & 0.3925 & $0.5894^{*}$ & 1.0000 & & & & & & & & & & & & & \\
\hline (4) & $\begin{array}{l}\text { Time in } \\
\text { management }\end{array}$ & 0.3113 & 0.3743 & $0.6662^{*}$ & 1.0000 & & & & & & & & & & & & \\
\hline (5) & Femininity & -0.0475 & 0.0462 & 0.1014 & $\mid-0.3160$ & 1.0000 & & & & & & & & & & & \\
\hline (6) & Masculinity & 0.0202 & 0.2123 & 0.0509 & -0.1266 & $0.4709^{*}$ & 1.0000 & & & & & & & & & & \\
\hline (7) & Communality & -0.0338 & -0.1704 & -0.1972 & -0.3219 & 0.4853* & 0.2668 & 1.0000 & & & & & & & & & \\
\hline (8) & Gender identity & -0.2485 & -0.2177 & -0.0276 & -0.1724 & $0.5500^{*}$ & $0.3559 *$ & $0.3637^{*}$ & 1.0000 & & & & & & & & \\
\hline (9) & Agency & 0.0323 & 0.0451 & -0.0580 & -0.1398 & $0.5439 *$ & $0.6419 *$ & $0.5503^{*}$ & $0.4323 *$ & 1.0000 & & & & & & & \\
\hline (10) & $\begin{array}{l}\text { Discrimination } \\
\text { denial }\end{array}$ & \begin{tabular}{|l|}
-0.2789 \\
\end{tabular} & -0.2259 & 0.0041 & -0.4228 & 0.3463 & $0.3888^{*}$ & 0.2326 & 0.3261 & $0.5444^{*}$ & 1.0000 & & & & & & \\
\hline (11) & Resignation & $\mid-0.0279$ & -0.0972 & -0.0697 & -0.1959 & 0.1866 & 0.2055 & 0.2768 & 0.3527 & 0.3579* & $0.4791^{*}$ & 1.0000 & & & & & \\
\hline (12) & Resilience & $\mid-0.1741$ & -0.0582 & 0.0562 & $\mid-0.1893$ & 0.1415 & 0.1809 & 0.2257 & 0.2505 & 0.1154 & 0.2754 & 0.1619 & 1.0000 & & & & \\
\hline (13) & Aceptance & $\mid-0.2642$ & -0.0788 & 0.0225 & -0.0626 & 0.1165 & -0.0055 & 0.0397 & 0.2682 & 0.2535 & 0.2123 & -0.1866 & 0.2668 & 1.0000 & & & \\
\hline (14) & Distancing & $\mid-0.1528$ & -0.0535 & -0.1804 & -0.1734 & 0.2909 & $0.4729 *$ & 0.2357 & 0.2389 & 0.2500 & $0.4254^{*}$ & 0.3558 & 0.0945 & -0.1054 & 1.0000 & & \\
\hline (15) & Willingness & 0.1467 & 0.1204 & 0.0004 & 0.0086 & 0.3004 & $0.6518^{*}$ & $0.4790^{*}$ & 0.3084 & 0.6753* & 0.3451 & 0.3146 & 0.2114 & 0.0745 & 0.2440 & 1.0000 & \\
\hline (16) & Commitment & 0.2164 & 0.1504 & 0.1340 & \begin{tabular}{|l|}
-0.0391 \\
\end{tabular} & 0.2604 & $0.7223^{*}$ & 0.3153 & 0.2934 & $0.5676^{*}$ & 0.3545 & 0.2479 & 0.2465 & 0.0461 & 0.2366 & $0.7113^{*}$ & 1.0000 \\
\hline
\end{tabular}

Source: Elaborated by the authors.

Note: * indicates a significance level of $1 \%$

The test of the hypotheses confirmed hypothesis 1 (H1). As observed in Table 5, there was communality between leadership and femininity $(\beta=0.4126, p<0.01)$; that is, the higher the degree of femininity, the greater the gender identification $(\beta=0.4079, p<0.01)$. The hypothesis is valid also regarding masculinity: leaders with such latent traits tend to be more agentic $(\beta=0.6912, p<0.01)$. They do not lose identification with the female gender $(\beta=0.2828, p<0.01)$, but perceive it with less intensity $(\beta$ masc $=0.2828<\beta$ femin $=0.4079)$. It is also worth mentioning the high explanatory power of the model, despite the sample restricted to fifty managers.

Table 5

H1 Test

\begin{tabular}{l|c|c|c|c}
\hline Femininity & Communality & Gender Id & Agency & Gender Id \\
\hline Masculinity & $\begin{array}{c}0.4126^{* * *} \\
(0.1072)\end{array}$ & $\begin{array}{c}0.4079 * * * \\
(0.0867)\end{array}$ & - & - \\
\hline Constant & - & - & $\begin{array}{c}0.6912 * * * \\
(0.1191)\end{array}$ & $\begin{array}{c}0.2828^{* * *} \\
(0.1040)\end{array}$ \\
\hline Observations & $\begin{array}{c}4.3921^{* * *} \\
(0.4422)\end{array}$ & $\begin{array}{c}2.3566^{* * *} \\
(0.3609)\end{array}$ & $\begin{array}{c}3.1545^{* * *} \\
(0.4645)\end{array}$ & $\begin{array}{c}2.9403^{* * *} \\
(0.4068)\end{array}$ \\
\hline R-squared & 50 & 53 & 50 & 53 \\
\hline
\end{tabular}

Source: Elaborated by the authors.

Note: Standard errors are expressed in parentheses, and *** indicate a significance level of $1 \%$

The results shown in Table 6 partially support $\mathrm{H} 2$ since the larger the agency, the greater the reported prejudice $(\beta=0.5708$, $p<0.01)$, whereas the greater the masculinity, the greater the discrimination denial $(\beta=0.7638, p<0.01)$. Compared to the models of the first hypothesis, there is a reduction in explanatory power (R-square). 
Table 6

H2 Test

\begin{tabular}{l|c|c}
\hline Agency & Vestige of prejudice & Discrimination denial \\
\hline Masculinity & $\begin{array}{c}0.5708^{* * *} \\
(0.1459)\end{array}$ & - \\
\hline Constant & - & $\begin{array}{c}0.7638^{* * *} \\
(0.2534)\end{array}$ \\
\hline Observations & 1.1882 & $\begin{array}{c}1.4353 \\
(0.9915)\end{array}$ \\
\hline R-squared & $(0.8386)$ & 53 \\
\hline
\end{tabular}

Source: Elaborated by the authors.

Note: Standard errors are expressed in parentheses, and

$* * *$ indicate a significance level of $1 \%$

As for $\mathrm{H} 3$, about the extent to which agentic leadership, which incorporates the male social role, explains less resignation and female resistance (Table 7), the results do not support the hypothesis, resulting in a negative relationship between the variables. In other words, while agentic leadership is related to greater resignation $(\beta=0.7656, p<0.01)$, the effect of masculinity is not significantly different from zero $(\beta=0.5609, p>0.10)$. This result is probably due to the low explanatory power of the model $\left(R^{2}=0.04\right)$.

Table 7

\section{H3 Test}

\begin{tabular}{l|c|c}
\hline Agency & Resignation & Resignation \\
\hline Masculinity & $\begin{array}{c}0.5708 * * * \\
(0.1459)\end{array}$ & - \\
\hline Constant & - & $\begin{array}{c}0.5609 \\
(0.3855)\end{array}$ \\
\hline Observations & -0.0370 & 2.2504 \\
$(1.6905)$ & $(1.5026)$ \\
\hline R-squared & 51 & 50 \\
\hline
\end{tabular}

Source: Elaborated by the authors.

Note: Standard errors are expressed in parentheses, and

$* * *$ indicate a significance level of $1 \%$

Regarding the hypotheses $\mathrm{H} 4$ and $\mathrm{H} 5$, more agentic and masculine leadership presented by female managers does not necessarily mean higher resilience indices $(\beta=0.1837$ and $\beta=0.3026, p>0.10$, respectively) or acceptance of their careers ( $\beta=0.5545$ and $\beta=-0.0127, p>0.10$, respectively). As with $\mathrm{H} 3$, the non-significance may be due to the low explanatory powers of the model, which is below $6 \%$ (Table 8). 
Table 8

H4 and H5 Test

\begin{tabular}{l|c|c|c|c}
\hline & Resilience & Resilience & Acceptance & Acceptance \\
\hline Agency & $\begin{array}{c}0.1837 \\
(0.2383)\end{array}$ & - & $\begin{array}{c}0.5545 \\
(0.3190)\end{array}$ & - \\
\hline Masculinity & - & $\begin{array}{c}0.3026 \\
(0.2480)\end{array}$ & - & $\begin{array}{c}-0.0127 \\
(0.3466)\end{array}$ \\
\hline Constant & 5.0719 & $4.9756^{* * *}$ & 1.9578 & $\begin{array}{c}5.1786 * * * \\
(1.3259)\end{array}$ \\
\hline Observations & $(1.3694)$ & $(0.9488)$ & $(1.8330)$ & 46 \\
\hline R-squared & 46 & 46 & 46 & 0.0000 \\
\hline
\end{tabular}

Source: Elaborated by the authors.

Note: Standard errors are expressed in parentheses, and *** indicate a significance level of $1 \%$

As for hypothesis $\mathrm{H6}$, that more agentic and masculine leadership presented by female managers are connected to a greater distance from the working teams and less willingness to support other women, the findings reveal partial support of the hypothesis. In general, both female and male agentic leaders maintain greater distance from their teams $\left(\beta_{\text {agency }}=0.3746\right.$, $\left.p<0.10 ; \beta_{\text {masculinity }}=0.9190, p<0.01\right)$, as well as greater willingness to support other women when required $\left(\beta_{\text {agency }}=0.9750\right.$, $p<0.01 ; \beta_{\text {masculinity }}=1.1142, p<0.01$.

Table 9

H6 Test

\begin{tabular}{l|c|c|c|c}
\hline Agency & Distance & Distance & Willingness & Willingness \\
\hline Masculinity & $\begin{array}{c}0.3746 * \\
(0.2073)\end{array}$ & - & $\begin{array}{c}0.9750 * * * \\
(0.1521)\end{array}$ & - \\
\hline Constant & - & $\begin{array}{c}0.9190 * * * \\
(0.2471)\end{array}$ & - & $\begin{array}{c}1.1142 * * * \\
(0.1871)\end{array}$ \\
\hline Observations & 0.4346 & -0.8837 & $-1.9416 * *$ & -0.5700 \\
\hline R-squared & $(1.2282)$ & $(0.9632)$ & $(0.9012)$ & $(0.7293)$ \\
\hline
\end{tabular}

Source: Elaborated by the authors.

Note: Standard errors are expressed in parentheses, and *,**, and

$* * *$ indicate the significance level of $10 \% .5 \%$, and $1 \%$, respectively.

Finally, Table 10 presents the results of the $\mathrm{H} 7$ test. Both masculinity and agency are positively and significantly related to career commitment $\left(\beta_{\text {agency }}=0.8606, p<0.01 ; \beta_{\text {masculinity }}=1.3650, p<0.01\right)$. The $\mathrm{R}^{2}\left(\mathrm{R}_{\text {agency }}^{2}=0.3221\right.$ and $\left.\mathrm{R}_{\text {masculinity }}=0.5218\right)$, however, indicate that the more agentic or masculine the female managers, the greater their commitment to work. 
Table 10

H7 Test

\begin{tabular}{l|c|c}
\hline & Commitment & Commitment \\
\hline Agency & $\begin{array}{c}0.8606^{* * *} \\
(0.1783)\end{array}$ & - \\
\hline Masculinity & - & $1.3650^{* * *}$ \\
& & $(0.1886)$ \\
\hline Constant & -1.4980 & $-1.7501^{* *}$ \\
& $(1.0567)$ & $(0.7351)$ \\
\hline Observations & 51 & 50 \\
\hline R-squared & 0.3221 & 0.5218 \\
\hline
\end{tabular}

Source: Elaborated by the authors.

Note: Standard errors are expressed in parentheses, and *,**, and

$* * *$ indicate the significance level of $10 \% .5 \%$, and $1 \%$, respectively.

That said, Box 1 summarizes the results of the hypotheses tests.

\section{Box 1}

Tests of hypotheses

\begin{tabular}{|c|l|c|}
\hline Hypotheses & \multicolumn{1}{|c|}{ Description } & Supported \\
\hline H1 & $\begin{array}{l}\text { The greater the femininity (or masculinity) of the female manager, the greater the } \\
\text { communality (agency) and the gender identity (male/female) }\end{array}$ & Yes \\
\hline H2 & $\begin{array}{l}\text { The more agentic/masculine is the female manager, the lower the vestige of prejudice } \\
\text { (the greater the discrimination denial). }\end{array}$ & Partial \\
\hline H3 & The more agentic/masculine, the lower the resignation (lower the resistance) & Partial \\
\hline H4 & The more agentic/masculine, the greater the resilience in the management career. & No \\
\hline H5 & The more agentic/masculine, the greater the acceptance in the management career. & No \\
\hline H6 & $\begin{array}{l}\text { The more agentic/masculine, the greater the distance; and less willingness to support } \\
\text { other women. }\end{array}$ & Partial \\
\hline H7 & The more agentic/masculine, the greater the career commitment. & Yes \\
\hline
\end{tabular}

Source: Research data.

\section{CONCLUSION}

From the data collected, it was observed that women still suffer prejudices validated by male codes in their search for ascension to positions of greater responsibility and leadership, requiring them to prove more frequently and intensely their professional capacity.

The notion of "generic essentialism," which links prejudice to the biological nature of man-woman, still stands as a factor of legitimation to the barriers to female professional advancement. In this case, changing such a view will require time, struggle, and desire.

The sense of achievement for women, once limited to the family universe, is increasingly expanding to the world of work. Also, women currently seek financial independence, enabling them to overcome male dependency and subordination. Financial independence gives women freedom as well as a sense of ownership of their existence. Freedom that, however, does not remove from women the desire to start a family. On the contrary, it allows them to choose the form of family that best suits their desire. 
Female leadership: perceptions, reflections, and challenges in public administration
Renata Kessler Miltersteiner | Fátima Bayma de Oliveira Lygia Gonçalves Costa Hryniewicz | Anderson de Souza Sant'Anna

The quest of women seeking to occupy more strategic positions in organizations, and achieving higher education and technical competence, go through the challenge of overcoming tangible and intangible stereotypes of resuming fragility and barriers to ascension. By resisting the hegemonic paradigms of leadership and management, incorporating more humane and empathic policies and practices, they open the door to behavioral revolutions that are needed in modern society. They are on the path of bringing new meanings to work, management, and leadership.

Nevertheless, women are still in an unfavorable environment, which ignores their potential to overcome already exhausting business and organizational models. Selecting a professional solely because of their gender, ethnicity, or religion is a discriminatory attitude. It cannot be ignored that diversity is a value and irrefutable factor for innovation, creation, and humanization of living and working spaces. The change in mindset, too, cannot be limited to law enforcement but can advance through the spread of values and education.

Making changes of this magnitude is not a simple task, but it can be done with willingness and inclusive policies. In this study, the data suggest that when women perceive that others are experiencing the same difficulties and challenges they went through, they may feel more engaged and aware of common particularities and possibilities.

An agenda for change, inspired by more solidary than competitive values, is relevant to build more inclusive and participatory citizenship. Consequently, to build institutions able to mediate and regulate the relationships among individual-workorganizations-society that characterize, in particular, the transition to the so-called "Digital Economy" or "Fourth Industrial Revolution," whose changes in societal and organizational structures and dynamics are unprecedented (SCHWAB, 2016). The research data indicate, for example, the risks of intensifying the phenomenon of polarization of professions. Because of the reduced number of women in undergraduate programs of technology, mechatronics, research, development, and innovation, the space gained in the past few years may decrease in the next generation, as these areas will be the most valued occupations in the labor market (SANT'ANNA and MELLO, 2018; SUSSKIND and SUSSKIND, 2017).

Women played a decisive role in the political, social, economic, and behavioral transformations that forged the struggle for rights and modes of relationship that extrapolate the male-female duality. The prominent place of feminist movements in the civilizational achievements of the twentieth century is undeniable. In this contemporary context of transition that new, more feminine, human, and inclusive styles of power, leadership, and management are indispensable. This is a civilizing agenda, an agenda of the humankind. 
Female leadership: perceptions, reflections, and challenges in public administration
Renata Kessler Miltersteiner | Fátima Bayma de Oliveira Lygia Gonçalves Costa Hryniewicz | Anderson de Souza Sant'Anna

Luiz Carlos Moura

\section{REFERENCES}

ARVATEA, P. R.; GALILEAB, G. W.; TODESCATC, I. The queen bee: A myth? The effect of top-level female leadership on subordinate females. The Leadership Quarterly, v. 29, n. 5, p. 533-548, Oct. 2018.

BERTIOL, M. I. S. Ser administradora é o feminino de ser administrador? In: ENCONTRO DA ASSOCIAÇÃO NACIONAL DE PÓS-GRADUAÇÃO EM ADMINISTRAÇÃO, 24. 2000, Atibaia. Anais... Atibaia: ENANPAD, 2000. 1 CD-ROM.

CARVALHO, M. D.; CARVALHO, J. D.; CARVALHO, F. A. O Ponto de Vista Feminino na Reflexão Ética: Histórico e Implicações para a Teoria de Organizações. In: ENCONTRO DA ANPAD, 25., 2001, Campinas. Anais... Campinas: ANPAD, 2001.

DERKS, B.; LAARB, C. V.; ELLEMERS, N. The queen bee phenomenon:Why women leaders distance themselves from junior women. The Leadership Quarterly, v. 27, n. 3, p. 456-469, June 2016.

EAGLY, A.; CARLI, L. L. Women and the Labyrinth of Leadership. Harvard Business Review, p. 62-71, Sept. 2007.

HARAWAY, D. Gênero para um dicionário marxista: a política sexual de uma palavra. Cadernos Pagú, n. 22, p. 201-246, 2004.

HIRATA, H.; KERGOAT, D. Novas configurações da divisão sexual do trabalho. Caderno de pesquisa, v. 37, n. 132, p. 595-609, Sept./ Dec. 2007.

HRYNIEWIC, L. G. C; VIANNA, M. A. Mulheres em posição de liderança: obstáculos e expectativas de gênero em cargos gerenciais. Caderno EBAPE.BR, Rio de Janeiro, v. 16, n. 3, p. 331-344, July/ Sept. 2018.

IRIGARAY, H. A. R. Orientação Sexual e Trabalho. GV Executivo, v. 10, n. 2, p. 44-47, 2011.

INSTITUTO BRASILEIRO DE GEOGRAFIA E ESTATÍSTICA - IBGE. Pesquisa nacional por Amostra de Domicílios Contínua - PNAD C. Rio de Janeiro: IBGE, 2017.

JESUS, J. G. Orientações sobre identidade de gênero: conceitos e termos. Brasília, DF: [s.n.], 2012. Available at: <http://www.diversidadesexual. com.br/wp-content/uploads/2013/04/G\%C3\%8ANERO-CONCEITOSE-TERMOS.pdf>. Acessed on: Apr. 20, 2017.

KANAN, L. A. Poder e liderança de mulheres nas organizações de trabalho. Revista Organizações \& Sociedade, v. 17, n. 53, p. 243257, Apr./June 2010.
MAVIN, S.; BRYANS, P. Gender on the agenda in management education?. Women In Management Review, v. 14, n. 3, p. 99-104, 1999. Available at: <http://doi.org/10.1108/09649429910269901>. Accessed on: May 28, 2020.

LEE, L. E. et al. Women on boards: global trends in gender diversity on corporate boards. New York: MSCl, 2018. (Research Insights).

MELO, H. P.; THOMÉ, D. Mulheres e Poder. Rio de Janeiro: Ed. FGV, 2018.

NOGUEIRA, E. C. Sentidos do Exercício da Liderança por Mulheres Executivas Brasileiras. 2012. Master Thesis (Master Degree in Administration) - Universidade Municipal de São Caetano do Sul, São Paulo, 2012.

OLIVEIRA, F. B.; MENEZES, M.; SANT'ANNA, A. S. Percepções sobre os valores das mulheres no mercado de trabalho. In: CONGRESO INTERNACIONAL DEL CLAD, 17., 2012, Caracas. Anais... Caracas: CLAD, 2012.

OLIVEIRA, R. Elogio da diferença: O feminino Emergente. Brasiliense, 1993.

SANT'ANNA, A. S.; MELLO, A. M. G. Remuneração Femina. São Paulo: Aliança para o Empoderamento das Mulheres - ONU Mulher. (Relatório de Pesquisa).

SCHWAB, K. A quarta revolução industrial. São Paulo: EDIPRO, 2016.

SCOTT, J. Gender: A useful category of historical analysis. The American Historical Review, v. 91, n. 5, p. 1053-1101, 1986.

SIQUEIRA, A. C. F.; SALES, R, G.; FISCHER, R. M. Diversidade nas Organizações: Uma Análise Sistemática da Produção Acadêmica da Área de Administração entre 2010 e 2015. In: ENCONTRO DA ANPAD, 40., 2016, Salvador. Anais... Salvador: ANPAD, 2016.

SUSSKIND, R.; SUSSKIND, D. The future of the professions: how technology will transform the work of human experts. Glasgow: Oxford Press, 2017.

TAJFEL, H.; TURNER, J. C. An integrative theory of intergroup conflict. In: WORCHEL, S.; AUSTIN, W. G. (Eds.). The Social Psycology of Intergroup relations. Chicago: Nelson Hall, 1979.

TEIXEIRA, S. Gestão das Organizações. Madrid: McGrawHill, 2005.

TEIXEIRA, S. Gestão das Organizações. Madrid: McGrawHill, 1998. 
Renata Kessler Miltersteiner

ORCID: https://orcid.org/0000-0003-4884-4133

Master in Public Administration from the Brazilian School of Public and Business Administration of Fundação Getúlio Vargas (FGV EBAPE); Financial Planning Coordinator at the State Secretariat of Finance of the State of Rio de Janeiro, Rio de Janeiro - RJ, Brazil. Researcher on Gender and Female Leadership. E-mail: renata.mil@gmail.com

\section{Fátima Bayma de Oliveira}

ORCID: https://orcid.org/0000-0001-5158-9546

PhD in Education from the Federal University of Rio de Janeiro (UFRJ); Full Professor at Fundação Getulio Vargas in Masters and Doctorate in Business Administration at the Brazilian School of Public and Business Administration (FGV EBAPE), Rio de Janeiro- RJ, Brazil. E-mail: fatima.oliveira@fgv.br

Lygia Gonçalves Costa Hryniewicz

\section{ORCID: https://orcid.org/0000-0001-5553-0955}

Researcher at the Research Center in Social Stratification and Trajectories of the Federal University of Rio de Janeiro (PATHS/UFRJ); PhD in Sociology by the Brazilian Society of Instruction at the University Research Institute of Rio de Janeiro (SBI/IUPERJ); Postdoctoral at the Institute of Urban and Regional Planning and Research of the Federal University of Rio de Janeiro (IPPUR/UFRJ). E-mail: Iygcosta@gmail.com

Anderson de Souza Sant'Anna

ORCID: https://orcid.org/0000-0001-6537-6314

Postdoctorate in Psychoanalytic Theory at the Federal University of Rio de Janeiro (UFRJ); PhD in Administration and PhD in Architecture and Urbanism from the Federal University of Minas Gerais (UFMG); Adjunct Professor at the São Paulo School of Business Administration at Fundação Getulio Vargas (FGV EAESP), São Paulo-SP, Brazil. E-mail: anderson.santanna@fgv.br

\section{Luiz Carlos Moura}

ORCID: https://orcid.org/0000-0001-8543-231X

PhD in Business Administration from the Brazilian School of Public and Business Administration of the Getulio Vargas Foundation (FGV EBAPE); Collaborating Professor at the Faculty of Management and Accounting, Federal University of Rio de Janeiro (UFRJ), Rio de Janeiro - RJ, Brazil. E-mail: Icarlos_moura@hotmail.com 